\title{
EFFICACY OF VARIOUS NPK APPLICATION METHODS ON THE YIELD OF DIFFERENT SUNFLOWER (HELIANTHUS ANNUUS L.) GENOTYPES GROWN DURING SPRING SEASONS
}

\author{
MAHMOOD, H. N. \\ Biotechnology and Crop Science Department, College of Agricultural Engineering Sciences, \\ University of Sulaimani, Sulaimani, Kurdistan Region, Iraq \\ (e-mail: hekmat.mahmood@univsul.edu.iq; phone: +964-7501-269-838)
}

(Received 23 $3^{\text {rd }}$ Aug 2020; accepted $30^{\text {th }}$ Nov 2020)

\begin{abstract}
Sunflower (Helianthus annuus L.) is a member of the Compositae family. It is one of the world's leading oilseed crops, mainly cultivated for its oil content. A field study was conducted at two different locations to determine the effect of various applications of NPK fertilizer on the yields of different genotypes. The experimental design was a complete block design, replicated three times. Fertilizer application methods (fertigation, foliar, and control) formed the main plots and three different sunflower genotypes (Sevar, Dea, Local) formed the sub-plots. The data was subjected to analysis of variance, and correlation coefficient and path analysis were used. Dea genotype had the highest achene yield of $8,384.721 \mathrm{~kg} \mathrm{ha}^{-1}$ under foliar applications at both locations. Correlation studies between achene yield and all its components were highly significant at both locations. However, 1000 achene weight at a second location, was not significant. The results showed that the maximum positive direct effect of 1.00 on achene yield was exerted by achene weight at both locations. This study indicated that achene weight is an important characteristic concerning the achene yield of sunflower.
\end{abstract}

Keywords: fertigation, foliar, correlation, path analysis, yield improvement

\section{Introduction}

Sunflower (Helianthus annuus L.) is a widely distributed and adaptable oilseed crop of the world. It is the fourth most commonly grown oil crop worldwide after oil-palm, soybean, and rapeseed which constitute over $87 \%$ of global vegetable oil productions, and it accounts for about 12\% of edible vegetable oil (Demir et al., 2006; Murphy, 2010; Siddiqi et al., 2012; Shafi et al., 2013; Taran et al., 2013; Hakim et al., 2013; Nasreen et al., 2015; Rauf et al., 2017). The crop is an essential oilseed crop consumed worldwide due to its high content of unsaturated fatty acids and zero cholesterol level, which are necessary for the human diet (Onemli and Gucer, 2010; Alberio et al., 2015). For optimal plant growth, nutrients must be present in sufficient and balanced quantities. Soil contains natural reserves of plant nutrients, but these reserves are mainly not available in the forms of plants. They have released only a small part through biological or chemical processes activity. Production of these nutrients naturally is not sufficient to meet the plant requirements. To compensate for these low nutrients, fertilizers must be used (Chen, 2006; Ahmad et al., 2010; Akbari et al., 2011). The ability to reach sunflower achenes maximum productivity is related, in part, with suitable mineral nutrition of the plant (Aquino et al., 2013). Fertilizer containing major nutrients is usually applied to meet the nutrient deficiencies of the soil; however, uptake of $\mathrm{N}$ is often low $(50 \%)$, which may have some environmental consequences (Scheiner et al., 2002). Hussain et al. (2000) reported that higher yields could be obtained by applying chemical fertilizers. Ultimately, the required fertilizers in the soil will increase the production of crops (Adediran et al., 2005). Nutrient management is one of the main factors that influence sunflower achene yield, achene oil, and fatty acid contents. Farmers have traditionally applied organic 
manure plus nitrogen $(\mathrm{N})$ and phosphate $(\mathrm{P})$ fertilizers, resulting in overuse of $\mathrm{N}$ and $\mathrm{P}$ but insufficient potassium (K) input in sunflower production (Tuo et al., 2010). Nitrogen, phosphorus, and potash are the main nutrients, which are likely to become deficient in most soils, and their application usually results in increased production. Nitrogen $(\mathrm{N})$ is the most nutrient required by sunflowers and has an impact on seed size, leaf numbers and sizes, seed weight, and seed yields. However, increasing the $\mathrm{N}$ rate increases seed protein, but decreases oil concentration (Darby et al., 2013). Phosphorus (P) and Potassium $(\mathrm{K})$ are coming in second because these nutrients are naturally available in the soil and consider low soluble compounds.

Fertigation application methods is a technique, which can reduce the cost of fertilizer use by eliminating operating and improving the efficiency of nutrient. Also, it could conceivably reduce leaching or denitrification (gaseous) losses of nitrogen and lower the luxury uptake of nutrients by plants. Combined application of irrigation and nitrogen through fertigation is now becoming a common practice in modern agriculture because of its advantages over broadcast $\mathrm{N}$ application. The $\mathrm{N}$-fertigation was found efficient for growth and yield of sunflower (Popoola et al., 2016). Hebbar et al. (2004), reported that reduced loss of nutrients could be through fertigation compared to soil application of fertilizer. Fertigation allows users to put the fertilizers in the plant root zone or on the canopy at the desired frequency, amount, and concentration at the appropriate time (Kumar et al., 2000).

Foliar application of nitrogen was beneficial to sunflower growth, development, and yield (Haseeb and Maqbool, 2015). The time and duration of foliar application determine the fate of plant yield (Varga and Svecnjak, 2006). It is since foliar-applied nitrogen is absorbed by plants more rapidly than other methods. Nitrogen is considered to be an essential part of different structural and metabolic compounds in plants (Hassan et al., 2010).

Many researchers use correlation coefficient and path analysis. Path analysis provides information about the direct and indirect effect character on seed yield, and it helps in examining the relative contribution of individual variables towards sunflower seed yield (Janamma et al., 2008). Correlation coefficient and path coefficient analysis assists in identifying the traits that are useful and helps in the selection of superior criteria to improve achene yield.

The objective of this study was to investigate the effect of both (fertigation and foliar NPK application) on achene yield and yield components of three sunflower genotypes.

\section{Material and Methods}

\section{Plant material and location of the experiment}

This study was conducted in two different locations in the government of Sulaimani, Kurdistan Region of Iraq. The first location, Agricultural Research Station at Kanipanka (Longitude of $045^{\circ} 43^{\prime} 22^{\prime \prime} \mathrm{E}$, the altitude of $548 \mathrm{masL}$, and latitude of $35^{\circ} 22^{\prime} 22^{\prime \prime} \mathrm{N}$ ), in Sharazoor intermountain $35 \mathrm{~km}$ east of Sulaymaniyah. The second location, Qlyasan, the experimental station of the College of Agricultural Engineering Sciences, the University of Sulaimani, (latitude: $35^{\circ} 34^{\prime} 17^{\prime \prime} \mathrm{N}$, Longitude: $045^{\circ} 22^{\prime} 00$ ' E, altitude: 757 masL) from April to July 2017. The climate is a semi-arid environment; hot and dry in summer, cold and wet in winter, and rainy season autumn to winter. During that period, the temperature ranged from $18^{\circ} \mathrm{C}$ to $39^{\circ} \mathrm{C}$, and the average relative humidity was $31 \%$ in the region (Kurdistan Regional Government, 2018; see Table 1). 
Table 1. Agrometeorological parameters at Kanipanka and Qlyasan locations 2017

\begin{tabular}{c|c|c|c|c}
\hline \multirow{2}{*}{ Locations } & \multirow{2}{*}{ Month } & \multicolumn{2}{|c|}{ Air Temperature ${ }^{\circ} \mathbf{C}$} & Relative humidity \\
\cline { 3 - 4 } & & Minimum & Maximum & 42 \\
& April & 11.24 & 23.62 & 30.3 \\
\multirow{3}{*}{ Kanipanka } & May & 15.75 & 33.54 & 21.4 \\
& June & 21.01 & 39.73 & 19 \\
\hline \multirow{3}{*}{ Qlyasan } & July & 26.7 & 44.57 & 55 \\
& April & 11.00 & 34.00 & 35 \\
& May & 13.00 & 40.00 & 28 \\
& June & 21.00 & 47.00 & 20 \\
\hline
\end{tabular}

\section{Soil sampling and analysis}

The soil samples were collected at a depth of 0-60 $\mathrm{cm}$ for laboratory analysis at each location. It was air-dried gently, crushed, and tested for physical and chemical properties. Details of soil properties are shown in Table 2.

Table 2. Physicochemical properties of the soil samples for locations of the experimental field

\begin{tabular}{|c|c|c|c|}
\hline \multirow{2}{*}{\multicolumn{2}{|c|}{ Physicochemical properties }} & \multicolumn{2}{|c|}{ Locations } \\
\hline & & \multirow{2}{*}{$\begin{array}{l}\text { Kanipanka } \\
36\end{array}$} & Qlyasan \\
\hline \multirow{4}{*}{$\begin{array}{c}\text { Particle size } \\
\text { distribution }\left(\mathrm{g} \mathrm{kg}^{-1}\right)\end{array}$} & Sand & & 107 \\
\hline & Silt & 529 & 435 \\
\hline & Clay & 435 & 458 \\
\hline & Texture class & Silty Clay & Silty Clay \\
\hline \multirow{3}{*}{\multicolumn{2}{|c|}{$\begin{array}{c}\text { Total Nitrogen }\left(\mathrm{mg} \mathrm{kg}^{-1}\right) \\
\text { Available Phosphate }\left(\mathrm{mg} \mathrm{kg}^{-1}\right) \\
\text { Soluble Potassium }\left(\mathrm{mmol} \mathrm{L}^{-1}\right)\end{array}$}} & 1.03 & 1.07 \\
\hline & & 7.2 & 6.28 \\
\hline & & 0.06 & 0.06 \\
\hline \multirow{4}{*}{\multicolumn{2}{|c|}{$\begin{array}{c}\mathrm{PH} \\
\mathrm{EC}\left(\mathrm{dS} \mathrm{m} \mathrm{m}^{-1}\right) \\
\text { Organic matter }\left(\mathrm{g} \mathrm{kg}^{-1}\right) \\
\mathrm{CaCO}_{3}\left(\mathrm{~g} \mathrm{~kg}^{-1}\right)\end{array}$}} & 7.70 & 7.59 \\
\hline & & 0.22 & 0.49 \\
\hline & & 14.8 & 22.4 \\
\hline & & 208.3 & 304.3 \\
\hline
\end{tabular}

\section{Fertilizer placement methodology}

Liquid NPK fertilizer (20-20-20), EC Fertilizer: Guaranteed Content (W/W) \%. Nitrogen (N) 20\% Urea $\left(\mathrm{CH}_{4} \mathrm{~N}_{2} \mathrm{O}\right)$, Phosphorus (P) 20\% Phosphoric acid $\left(\mathrm{H}_{3} \mathrm{PO}_{4}\right)$, and Potassium (K) $20 \%$ Potassium Chloride (KCl). Three methods of application used during this study: Fertigation (application of fertilizers with irrigation water): as recommended for fertigation, 30 liters of NPK covering one hectare. The appropriate NPK rate was mixed with water, then applied with irrigation to the appropriate plot. Foliar application: To spraying sunflower leaves, 3 liters of NPK was mixed with 1000 liters of water, which is adequate to cover one hectare as recommended for foliar application. Spraying leaves with the appropriate rate were carried out where wind speed at minimal. Zero NPK application (control): This treatment is a no fertilizer added to the plot, NPK $(0,0,0)$. 


\section{Sunflower genotype}

The sunflower genotypes were a single cross hybrid Sevar, single cross hybrid Dea, were obtained from the Crop Improvement Department, University of Arizona, USA, and a Local genotype.

\section{Experimental design and treatments}

The treatments were carried out in a completely randomized design (RCBD) as a splitplot factorial experiment, with three methods of NPK fertilizer application (fertigation, foliar, and zeroes NPK fertilizer, as the main plot. At the same time, the sub-plot factors encompassed three sunflower genotypes (Sevar, Dea, and Local) with three repetitions, comprised of 27 experimental units. The sub-plot was $2 \mathrm{~m}$ by $1.2 \mathrm{~m}$ in size, and each consisted of two rows spaced at $0.60 \mathrm{~m}$ with a plant distance of $0.25 \mathrm{~m}$. The seeds were planted in line during April $6^{\text {th }}$, and $10^{\text {th }}$ of 2017 at the first and second locations respectively, after completion of germination, the seedlings were thinned out to one plant hole $^{-1}$. All the NPK application methods presented on the same day, then irrigated. The NPK application was applied in two equal doses. The first dose for both (fertigation and foliar) application were applied 25 days after sowing (DAS). The second dose was applied at 50 DAS.

\section{Data recorded}

At each location, five fully mature plants were harvested in each plot. Achene yield components and average achene yields per plot were recorded at a seed moisture content of about $10 \%$. The plant was harvested at 106 DAS at the first location (Kanipanka), while at 105 DAS, plants were harvested at the second location (Qlyasan), respectively.

Biological yield $\left(\mathrm{kg} \mathrm{ha}^{-1}\right)$ was measured as the above-ground biomass per plant by weighting the whole plants, including seeds and stalks from the plant samples collected during full maturity, expressed in metric grams, then converted to $\left(\mathrm{kg} \mathrm{ha}^{-1}\right)$.

Seed yield $\left(\mathrm{kg} \mathrm{ha}^{-1}\right)$ : The seed weight of the five representative plants was added to net plot seed weight, and later the average of seed yield was converted to $\left(\mathrm{kg} \mathrm{ha}^{-1}\right)$.

Harvest index, was expressed as the ratio of seed yield to biological yield (Singh and Stoskopf, 1971).

\section{Statistical analysis}

All data were subjected to statistical analysis by the technique of variance of the splitplot design using XLSTAT (2016). For a direct comparison of treatments, the least significant difference tests (LSD) at levels of 0.05 was used. For testing the main effects of NPK fertilizer application on sunflower genotypes, the data were subjected to analysis of variance (ANOVA).

\section{Results}

Data present in Table 3 explain the effect of methods of NPK application on achene yield and its components at both locations and their average. The results obtained from the variance analysis of data indicated that the NPK application methods influenced all studied characters highly significantly, except for the harvest index, which responded only significantly at the first location. In contrast, at the second location, the head diameter, a number of achenes plant ${ }^{-1}, 1000$ achene weight, and biological yield 
responded highly significantly to the effect of NPK application methods, while the significant effect was recorded for the head weight, achene weight, and achene yield. Still, no significant response was recorded for the harvest index. Regarding the average of both locations, all studied characters exhibited a highly significant response to the NPK application methods. At both locations and their average, the methods of fertigation and foliar NPK application exceeded the control treatment significantly (see Appendix).

Table 3. Effect of NPK application methods on achene yield and its components at both locations and their average

\begin{tabular}{|c|c|c|c|c|c|c|c|c|}
\hline $\begin{array}{c}\text { NPK } \\
\text { application } \\
\text { methods }\end{array}$ & $\begin{array}{c}\text { Head } \\
\text { diameter } \\
(\mathrm{cm})\end{array}$ & $\begin{array}{l}\text { Head } \\
\text { weight } \\
\text { (g) }\end{array}$ & $\begin{array}{c}\text { Achene } \\
\text { weight } \\
\text { (g) }\end{array}$ & $\begin{array}{c}\text { No. of } \\
\text { achenes } \\
\text { plant }^{-1}\end{array}$ & $\begin{array}{c}1000 \\
\text { Achene } \\
\text { weight } \\
\text { (g) }\end{array}$ & $\begin{array}{l}\text { Harvest } \\
\text { index }\end{array}$ & $\begin{array}{c}\text { Biological } \\
\text { yield } \\
\left(\mathrm{kg} \mathrm{ha}^{-1}\right)\end{array}$ & $\begin{array}{c}\text { Achene } \\
\text { yield } \\
\left(\mathrm{kg} \mathrm{ha}^{-1}\right)\end{array}$ \\
\hline \multicolumn{9}{|c|}{ First location } \\
\hline Fertigation & $19.931 \mathrm{a}$ & $191.204 \mathrm{a}$ & $124.780 \mathrm{a}$ & $1870.139 \mathrm{a}$ & $66.659 \mathrm{a}$ & $0.390 \mathrm{a}$ & $21210.269 \mathrm{a}$ & $8318.716 \mathrm{a}$ \\
\hline Foliar & $19.466 \mathrm{a}$ & $180.691 \mathrm{a}$ & $116.513 \mathrm{a}$ & $1850.454 \mathrm{a}$ & $62.842 \mathrm{a}$ & $0.377 \mathrm{a}$ & $20525.547 \mathrm{a}$ & $7767.564 \mathrm{a}$ \\
\hline Control & $14.121 \mathrm{~b}$ & $95.278 \mathrm{~b}$ & $64.160 \mathrm{~b}$ & $1312.216 \mathrm{~b}$ & $48.673 \mathrm{~b}$ & $0.299 \mathrm{~b}$ & $14602.814 \mathrm{~b}$ & $4277.381 \mathrm{~b}$ \\
\hline $\begin{array}{c}\text { LSD } \\
(\mathrm{P} \leq 0.05)\end{array}$ & 0.883 & 25.430 & 16.326 & 233.802 & 4.995 & 0.053 & 2182.515 & 1088.414 \\
\hline \multicolumn{9}{|c|}{ Second location } \\
\hline Fertigation & $16.960 \mathrm{a}$ & $134.050 \mathrm{a}$ & $83.903 \mathrm{a}$ & $1271.464 \mathrm{a}$ & $49.252 \mathrm{a}$ & $0.303 \mathrm{a}$ & $18223.180 \mathrm{a}$ & $5593.558 \mathrm{a}$ \\
\hline Foliar & $16.556 \mathrm{a}$ & $134.162 \mathrm{a}$ & $83.247 \mathrm{a}$ & $1350.677 \mathrm{a}$ & $51.032 \mathrm{a}$ & $0.300 \mathrm{a}$ & $18308.092 \mathrm{a}$ & $5549.831 \mathrm{a}$ \\
\hline Control & $13.528 \mathrm{~b}$ & $78.627 \mathrm{~b}$ & $47.989 \mathrm{~b}$ & $976.828 \mathrm{~b}$ & $41.569 \mathrm{~b}$ & $0.254 \mathrm{a}$ & $12358.803 \mathrm{~b}$ & $3199.268 \mathrm{~b}$ \\
\hline $\begin{array}{c}\text { LSD } \\
(\mathrm{P} \leq 0.05)\end{array}$ & 0.672 & 27.591 & 26.812 & 160.693 & 3.907 & N.S & 2554.827 & 1787.459 \\
\hline \multicolumn{9}{|c|}{ Average of both locations } \\
\hline Fertigation & $18.446 \mathrm{a}$ & $162.627 \mathrm{a}$ & $104.342 \mathrm{a}$ & $1570.802 \mathrm{a}$ & $57.955 \mathrm{a}$ & $0.347 \mathrm{a}$ & $19716.725 \mathrm{a}$ & $6956.137 \mathrm{a}$ \\
\hline Foliar & $18.011 \mathrm{a}$ & $157.426 \mathrm{a}$ & $99.880 \mathrm{a}$ & $1600.565 \mathrm{a}$ & $56.937 \mathrm{a}$ & $0.338 \mathrm{a}$ & $19416.819 \mathrm{a}$ & $6658.698 \mathrm{a}$ \\
\hline Control & $13.824 \mathrm{~b}$ & $86.952 \mathrm{~b}$ & $56.075 \mathrm{~b}$ & $1144.522 \mathrm{~b}$ & $45.121 \mathrm{~b}$ & $0.277 \mathrm{~b}$ & $13480.808 \mathrm{~b}$ & $3738.324 \mathrm{~b}$ \\
\hline $\begin{array}{c}\text { LSD } \\
(\mathrm{P} \leq 0.05)\end{array}$ & 0.461 & 15.585 & 13.038 & 117.833 & 2.634 & 0.036 & 1395.618 & 869.220 \\
\hline
\end{tabular}

LSD value for NPK at $\mathrm{P} \leq 0.01=$ Highly significant $* *$, LSD value at $\mathrm{P} \leq 0.05=$ Significant $*, \mathrm{~N} . \mathrm{S} .=$ Statistically non-significant

Table 4 shows the averages of achene yield and its components at both locations and their average for sunflower genotypes. The differences among genotypes were highly significant for all studied characters at both locations and their average except the harvest index and 1000 achene weight at the first and second locations, respectively, which was only significant. About the head diameter and the number of achenes plant ${ }^{-1}$, the highest value recorded by Sevar genotype, while the lowest value recorded by Local genotype at both locations and their average. The same trade was shown for the harvest index except for the second location, in which the Dea exhibited Sevar genotypes. No significant differences were found between Sevar and Dea genotypes for the number of achene plant $^{-1}$ at the first location and their average at both locations. However, and harvest index at the second location and their average at both locations. The head weight, achene weight, 1000 achenes weight, biological yield, and achene yield, and their average, Dea genotype produced the highest value at both locations. In the case of local genotype, 1000 achene weight at the second location, showed the highest value while Sevar genotype showed the lowest value. No significant differences were recorded between Sevar and Dea genotype for the head weight, 1000 achene weight at the second location. 
Table 4. Effect of sunflower genotypes on achene yield and its components at both locations and their average

\begin{tabular}{|c|c|c|c|c|c|c|c|c|}
\hline $\begin{array}{l}\text { Sunflower } \\
\text { genotypes }\end{array}$ & $\begin{array}{c}\text { Head } \\
\text { diameter } \\
(\mathrm{cm})\end{array}$ & $\begin{array}{l}\text { Head } \\
\text { weight } \\
\text { (g) }\end{array}$ & $\begin{array}{c}\text { Achene } \\
\text { weight } \\
\text { (g) }\end{array}$ & $\begin{array}{c}\text { No. of } \\
\text { achenes } \\
\text { plant }^{-1}\end{array}$ & $\begin{array}{c}1000 \\
\text { Achene } \\
\text { weight } \\
\text { (g) }\end{array}$ & $\begin{array}{c}\text { Harvest } \\
\text { index }\end{array}$ & $\begin{array}{c}\text { Biological } \\
\text { yield } \\
\left(\mathrm{kg} \mathrm{ha}^{-1}\right)\end{array}$ & $\begin{array}{c}\text { Achene } \\
\text { yield } \\
\left(\mathrm{kg} \mathrm{ha}^{-1}\right)\end{array}$ \\
\hline \multicolumn{9}{|c|}{ First location } \\
\hline Sevar & $20.071 \mathrm{a}$ & $149.824 \mathrm{~b}$ & $104.170 \mathrm{~b}$ & $1879.371 \mathrm{a}$ & $54.122 \mathrm{~b}$ & $0.387 \mathrm{a}$ & $17495.754 \mathrm{~b}$ & $6944.716 b$ \\
\hline Dea & $18.104 \mathrm{~b}$ & $187.248 \mathrm{a}$ & $126.895 \mathrm{a}$ & $1851.685 \mathrm{a}$ & $67.370 \mathrm{a}$ & $0.349 \mathrm{~b}$ & $23834.082 \mathrm{a}$ & $8459.687 \mathrm{a}$ \\
\hline Local & $15.342 \mathrm{c}$ & $130.100 \mathrm{c}$ & $74.388 \mathrm{c}$ & $1301.753 \mathrm{~b}$ & $56.681 \mathrm{~b}$ & $0.330 \mathrm{~b}$ & $15008.794 \mathrm{c}$ & $4959.257 \mathrm{c}$ \\
\hline $\begin{array}{c}\text { LSD } \\
(\mathrm{P} \leq 0.05)\end{array}$ & 0.779 & 13.306 & 11.134 & 159.797 & 3.460 & 0.035 & 1249.812 & 742.249 \\
\hline \multicolumn{9}{|c|}{ Second location } \\
\hline Sevar & $18.056 \mathrm{a}$ & $126.516 \mathrm{a}$ & $77.977 \mathrm{~b}$ & $1418.955 \mathrm{a}$ & $44.594 \mathrm{~b}$ & $0.308 \mathrm{a}$ & $16496.97 \mathrm{~b}$ & $5198.522 b$ \\
\hline Dea & $15.793 \mathrm{~b}$ & $131.353 \mathrm{a}$ & $86.220 \mathrm{a}$ & $1285.796 \mathrm{~b}$ & $47.073 \mathrm{ab}$ & $0.310 \mathrm{a}$ & $18506.315 \mathrm{a}$ & $5748.051 \mathrm{a}$ \\
\hline Local & $13.194 \mathrm{c}$ & $88.970 \mathrm{~b}$ & $50.941 \mathrm{c}$ & $894.218 \mathrm{c}$ & $50.187 \mathrm{a}$ & $0.239 \mathrm{~b}$ & $13886.788 \mathrm{c}$ & $3396.084 \mathrm{c}$ \\
\hline $\begin{array}{c}\text { LSD } \\
(\mathrm{P} \leq 0.05) \\
\end{array}$ & 0.686 & 9.236 & 5.720 & 106.969 & 3.573 & 0.026 & 988.116 & 381.335 \\
\hline \multicolumn{9}{|c|}{ Average of both locations } \\
\hline Sevar & $19.063 \mathrm{a}$ & $138.170 \mathrm{~b}$ & $91.074 \mathrm{~b}$ & $1649.163 \mathrm{a}$ & $49.358 \mathrm{c}$ & $0.347 \mathrm{a}$ & $16996.363 \mathrm{~b}$ & $6071.619 \mathrm{~b}$ \\
\hline Dea & $16.949 \mathrm{~b}$ & $159.301 \mathrm{a}$ & $106.558 \mathrm{a}$ & $1568.740 \mathrm{a}$ & $57.222 \mathrm{a}$ & $0.329 \mathrm{a}$ & $21170.198 \mathrm{a}$ & $7103.869 \mathrm{a}$ \\
\hline Local & $14.268 \mathrm{c}$ & $109.535 \mathrm{c}$ & $62.665 \mathrm{c}$ & $1097.986 \mathrm{~b}$ & $53.434 \mathrm{~b}$ & $0.284 \mathrm{~b}$ & $14447.791 \mathrm{c}$ & $4177.671 \mathrm{c}$ \\
\hline $\begin{array}{c}\text { LSD } \\
(\mathrm{P} \leq 0.05)\end{array}$ & 0.491 & 7.668 & 5.925 & 91.029 & 2.355 & 0.021 & 754.21 & 395.026 \\
\hline
\end{tabular}

LSD value for Sunflower genotype at $\mathrm{P} \leq 0.01=$ Highly significant $* *$, $L S D$ value at $\mathrm{P} \leq 0.05=$ Significant

$*$, N. S. = Statistically non-significant

As seen in Table 5 in which illustrate the interaction effect between NPK application methods and sunflower genotypes on achene yield and its components at both locations and their average. At the first location, all characters responded to this effect significant except biological yield. At the second location, all characters showed a significant response to the interaction effect, except 1000 achene weight and biological yield. While at the average of both locations, the head diameter, head weight, achene weight, number of achenes plant ${ }^{-1}$, and achene yield showed a highly significant response to this effect. Still, the 1000 achene weight and harvest index showed a significant response and not significant response produced by biological yield. The maximum value for head diameter recorded by the interaction between fertigation application and Sevar genotype with $22.543,20.167$ and $21.355 \mathrm{~cm}$ for both locations and their average respectively, but the lowest values were $12.527,11.583$ and $12.055 \mathrm{~cm}$, respectively, recorded by the interaction between the treatment of control and Local genotype. The highest value for the head weight, achene weight, and achene yield were recorded by the interaction between the foliar application associated with Dea genotype $225.450 \mathrm{~g}, 149.981 \mathrm{~g}$, and $9998.808 \mathrm{~kg} \mathrm{ha}^{-1}$, respectively at the first location. However, the values were $157.282 \mathrm{~g}$, $101.559 \mathrm{~g}$, and $6770.634 \mathrm{~kg} \mathrm{ha}^{-1}$, respectively, at the second location. While for the average of both locations, the values were $191.366 \mathrm{~g}, 125.770 \mathrm{~g}$, and $8384.721 \mathrm{~kg} \mathrm{ha}^{-1}$, respectively.

However, the lowest value for these characters was $85.380 \mathrm{~g}, 52.640 \mathrm{~g}$ and $3509.346 \mathrm{~kg} \mathrm{ha}^{-1}$, respectively at the first location and $59.343 \mathrm{~g}, 31.884 \mathrm{~g}$, and $2125.611 \mathrm{~kg} \mathrm{ha}^{-1}$ at the second location, while as the average of both locations were $72.362 \mathrm{~g}, 42.262 \mathrm{~g}$ and $2817.479 \mathrm{~kg} \mathrm{ha}^{-1}$, respectively. 
Table 5. Effect of the interaction between NPK application methods and sunflower genotypes on yield and its components at both locations and their average

\begin{tabular}{|c|c|c|c|c|c|c|c|c|c|}
\hline \multicolumn{2}{|c|}{$\begin{array}{c}\text { NPK Application } \\
\text { methods and } \\
\text { sunflower } \\
\text { genotypes }\end{array}$} & $\begin{array}{c}\text { Head } \\
\text { diameter } \\
(\mathrm{cm})\end{array}$ & $\begin{array}{l}\text { Head } \\
\text { weight } \\
\text { (g) }\end{array}$ & $\begin{array}{l}\text { Achene } \\
\text { weight } \\
\text { (g) }\end{array}$ & $\begin{array}{c}\text { No. of } \\
\text { achenes } \\
\text { plant }^{-1}\end{array}$ & $\begin{array}{c}1000 \\
\text { Achene } \\
\text { weight } \\
\text { (g) }\end{array}$ & $\begin{array}{c}\text { Harvest } \\
\text { index }\end{array}$ & $\begin{array}{c}\text { Biological } \\
\text { yield } \\
\left(\mathrm{kg} \mathrm{ha}^{-1}\right)\end{array}$ & $\begin{array}{l}\text { Achene } \\
\text { yield } \\
\left(\mathrm{kg} \mathrm{ha}^{-1}\right)\end{array}$ \\
\hline \multicolumn{10}{|c|}{ First location } \\
\hline \multirow{3}{*}{ Fertigation } & $\operatorname{var}$ & $22.543 \mathrm{a}$ & 188.2 & $137.089 \mathrm{a}$ & $2181.161 \mathrm{a}$ & $4 \mathrm{~b}$ & $0.449 \mathrm{a}$ & 203 & 913 \\
\hline & Dea & $20.250 \mathrm{~b}$ & $224.040 \mathrm{a}$ & $149.006 \mathrm{a}$ & $2055.619 \mathrm{a}$ & $72.754 \mathrm{a}$ & $0.386 \mathrm{bc}$ & $25733.018 \mathrm{a}$ & $9933.750 \mathrm{a}$ \\
\hline & Local & $17.000 \mathrm{c}$ & $161.309 \mathrm{~cd}$ & $88.246 \mathrm{c}$ & $1373.638 \mathrm{bc}$ & $64.388 \mathrm{~b}$ & 0.334 cde & $17545.577 \mathrm{a}$ & $5883.096 \mathrm{c}$ \\
\hline \multirow{3}{*}{ Foliar } & Sevar & $22.377 \mathrm{a}$ & $173.012 \mathrm{bc}$ & $117.278 \mathrm{~b}$ & $2164.527 \mathrm{a}$ & $54.191 \mathrm{c}$ & $0.406 \mathrm{ab}$ & 1938 & \\
\hline & Dea & $19.520 \mathrm{~b}$ & $225.450 \mathrm{a}$ & $149.981 \mathrm{a}$ & 1973. & $75.804 \mathrm{a}$ & $0.387 \mathrm{bc}$ & $796 \mathrm{a}$ & 999 \\
\hline & Local & $16.500 \mathrm{~cd}$ & 143. & $82.280 \mathrm{c}$ & 141 & $58.531 \mathrm{bc}$ & $0.337 \mathrm{~cd}$ & $71 \mathrm{a}$ & 548 \\
\hline \multirow{3}{*}{ Control } & Sevar & $15.293 \mathrm{de}$ & & $58.144 \mathrm{~d}$ & 129 & $45.342 \mathrm{~d}$ & $0.305 \mathrm{de}$ & $75 \mathrm{a}$ & 387 \\
\hline & Dea & $14.543 \mathrm{e}$ & 112.2 & & & $53.553 \mathrm{c}$ & $0.273 \mathrm{e}$ & $33 \mathrm{a}$ & 544 \\
\hline & Local & & & & & $47.125 \mathrm{~d}$ & & & \\
\hline \multicolumn{2}{|c|}{ LSD $(\mathrm{P} \leq 0.05)$} & & & & & & & & \\
\hline \multicolumn{10}{|c|}{ Second location } \\
\hline \multirow{3}{*}{ Fertigation } & & & & & $1507.304 \mathrm{~b}$ & & & & \\
\hline & Deo & 16 & $\mathrm{~b}$ & & & $7 \mathrm{a}$ & $\mathrm{abc}$ & & \\
\hline & Local & 13. & 11 & & $\mathrm{~d}$ & $02 \mathrm{a}$ & bcd & $3 \mathrm{a}$ & 43 \\
\hline \multirow{3}{*}{ Foliar } & Sevar & $18.917 \mathrm{~b}$ & $148.578 \mathrm{ab}$ & $92.199 \mathrm{a}$ & $2 \mathrm{a}$ & $46.895 \mathrm{a}$ & $0.338 \mathrm{a}$ & $3 \mathrm{a}$ & 614 \\
\hline & Dea & $16.667 \mathrm{c}$ & $157.282 \mathrm{a}$ & $101.559 \mathrm{a}$ & 136 & $50.647 \mathrm{a}$ & $0.322 \mathrm{ab}$ & $50 \mathrm{a}$ & 677 \\
\hline & Local & $14.083 \mathrm{~d}$ & & & & & $9 \mathrm{de}$ & $12 \mathrm{a}$ & $2 \mathrm{bc}$ \\
\hline \multirow{3}{*}{ Control } & Sevar & & & & & & & & 31 \\
\hline & Dea & $13.917 \mathrm{~d}$ & & & & $39.744 \mathrm{a}$ & & & 4320 \\
\hline & Local & & & & & $46.404 \mathrm{a}$ & & & 212 \\
\hline \multicolumn{2}{|c|}{$\operatorname{LSD}(\mathrm{P} \leq 0.05)$} & & & 9.907 & & & & & \\
\hline \multicolumn{10}{|c|}{ Average of both location } \\
\hline \multirow{3}{*}{ Fertigation } & Sevar & & 169. & $115.775 \mathrm{a}$ & & $55.581 \mathrm{~b}$ & & & 771 \\
\hline & & & 182. & 120. & & $61.790 \mathrm{a}$ & & & 804 \\
\hline & Local & 15. & 136 & $1 \mathrm{c}$ & & $56.495 \mathrm{~b}$ & $0.307 \mathrm{~cd}$ & $0 \mathrm{a}$ & 510 \\
\hline \multirow{3}{*}{ Foliar } & & & & & $5 \mathrm{a}$ & $50.543 \mathrm{c}$ & $0.372 \mathrm{ab}$ & 188 & $.583 \mathrm{~b}$ \\
\hline & Dea & $18.093 \mathrm{~b}$ & $191.366 \mathrm{a}$ & $125.770 \mathrm{a}$ & & $63.226 \mathrm{a}$ & $0.355 \mathrm{ab}$ & $23408.173 \mathrm{a}$ & $8384.721 \mathrm{a}$ \\
\hline & Local & & 120.1 & & & $57.043 \mathrm{~b}$ & $0.288 \mathrm{de}$ & $16027.191 \mathrm{a}$ & $4608.790 \mathrm{c}$ \\
\hline \multirow{3}{*}{ Control } & Sevar & $15.188 \mathrm{c}$ & & & & $41.951 \mathrm{~d}$ & $0.279 \mathrm{de}$ & $12619.285 \mathrm{a}$ & $3513.903 \mathrm{~d}$ \\
\hline & Dea & $14.230 \mathrm{~d}$ & $104.035 \mathrm{f}$ & $73.254 \mathrm{c}$ & $1359.462 \mathrm{c}$ & $46.649 \mathrm{c}$ & $0.292 \mathrm{de}$ & $16944.418 \mathrm{a}$ & $4883.591 \mathrm{c}$ \\
\hline & Local & $12.055 \mathrm{e}$ & $72.362 \mathrm{~g}$ & $42.262 \mathrm{e}$ & $903.972 \mathrm{e}$ & $46.764 \mathrm{c}$ & $0.258 \mathrm{e}$ & $10878.721 \mathrm{a}$ & $2817.479 \mathrm{e}$ \\
\hline \multicolumn{2}{|c|}{$\operatorname{LSD}(\mathrm{P} \leq 0.05)$} & & & & 157.667 & 4.078 & 0.036 & N.S & 684.205 \\
\hline
\end{tabular}

LSD value for interaction at $\mathrm{P} \leq 0.01=$ Highly significant **, LSD value for at $\mathrm{P} \leq 0.05=$ Significant *, N. S. = Statistically non-significant

Respect to the number of achene plant $^{-1}$, the values restricted between 1118.263 achenes for the interaction between control and local genotype to 2181.161 achenes for the interaction between fertigation application coupled with Sevar genotype at the first location, while at the second location and the average of both locations the values ranged between 689.682 and 903.972 achenes for the interaction between control and local genotype to 1701.722 and 1933.125 achenes for the interaction of foliar application associated with Sevar genotype. 
Concerning 1000 achene weight, the values of this character restricted between $45.342 \mathrm{~g}$ for the interaction between control and Sevar genotype to $75.804 \mathrm{~g}$ for the interaction between foliar and Dea genotype at the first location. However, the average values of both locations were between 41.951 to $63.226 \mathrm{~g}$.

Regarding the harvest index at the first location and the average of both locations, the highest values were 0.449 , and 0.391 recorded by the interaction of the fertigation application with Sevar genotype. However, for the interaction between foliar application with Sevar genotype, the highest value of 0.338 was recorded, at the second location. Interaction between control and Dea genotype, the lowest value was 0.273 at the first location. The lowest value of 0.198 , and 0.258 at the second location and the average of both locations exhibited by the interaction between control and Local genotype, respectively.

In this study, the effect of location on achene yield and its components, as shown in Table 6. The effect was highly significant for all characters, and the exceeding of the first location was significant. The first location predominated the second location by 13.76; $34.69 ; 41.98 ; 39.84 ; 25.60 ; 24.12 ; 15.24$ and $41.97 \%$ for the head diameter, head weight, achene weight, number of achenes plant ${ }^{-1}, 1000$ achene weight, harvest index, biological yield, and achene yield, respectively.

Table 6. Effect of locations on sunflower yield and its components

\begin{tabular}{c|c|c|c|c|c|c|c|c}
\hline Locations & $\begin{array}{c}\text { Head } \\
\text { diameter } \\
(\mathbf{c m})\end{array}$ & $\begin{array}{c}\text { Head } \\
\text { weight } \\
(\mathbf{g})\end{array}$ & $\begin{array}{c}\text { Achene } \\
\text { weight } \\
\mathbf{( g )}\end{array}$ & $\begin{array}{c}\text { No. of } \\
\text { Achenes } \\
\text { plant }^{-1}\end{array}$ & $\begin{array}{c}\mathbf{1 0 0 0} \\
\text { Achene } \\
\text { Weight } \\
\mathbf{( g )}\end{array}$ & $\begin{array}{c}\text { Harvest } \\
\text { index }\end{array}$ & $\begin{array}{c}\text { Biological } \\
\text { yield } \\
\left.\mathbf{( k g ~ h a}^{-1}\right)\end{array}$ & $\begin{array}{c}\text { Achene } \\
\text { yield } \\
\left(\mathbf{k g ~ h a}^{-1}\right)\end{array}$ \\
\hline $\begin{array}{c}\text { First } \\
\text { Second } \\
\text { LSD }\end{array}$ & $17.839 \mathrm{a}$ & $155.724 \mathrm{a}$ & $101.818 \mathrm{a}$ & $1677.603 \mathrm{a}$ & $59.391 \mathrm{a}$ & $0.355 \mathrm{a}$ & $18779.544 \mathrm{a}$ & $6787.885 \mathrm{a}$ \\
$(\mathrm{P} \leq 0.05)$ & 1.022 & 26.228 & 10.088 & 244.430 & 2.812 & 0.017 & 1915.131 & 672.505 \\
\hline
\end{tabular}

LSD value for locations at $\mathrm{P} \leq 0.01=$ Highly significant **, LSD value at $\mathrm{P} \leq 0.05=$ Significant *

The correlation coefficient was obtained among all pairs of study characters for achene yield and its components at the first location presented in Table 7. The head diameter exhibited a highly significant and positive correlation with head weight, achene weight, number of achenes plant ${ }^{-1}$, harvest index, and achene yield $(r=0.812,0.855,0.947,0.915$, and 0.855$)$ respectively. In contrast, this character produced a significant and positive correlation with biological yield $(\mathrm{r}=0.668)$. A highly significant and positive correlation was showed between head weight with achene weight, the number of achenes plant ${ }^{-1}$, 1000 achene weight, biological yield, and achene yield $(r=0.968,0.826,0.933,0.907$, and 0.968) respectively, but the correlation was significant and positive with harvest index $(r=0.759)$. Achene weight was highly significant and positively associated with the number of achenes plant ${ }^{-1}, 1000$ achene weight, harvest index, biological yield, and achene yield $(\mathrm{r}=0.916,0.863,0.799,0.927$, and 0.999$)$ respectively. A highly significant and positive correlation is recorded between the number of achenes plant ${ }^{-1}$ with harvest index and achene yield $(r=0.852$, and 0.916) respectively. Moreover, the number of achenes plant ${ }^{-1}$ produced a significant and positive correlation with biological yield $(\mathrm{r}=$ 0.792). 1000 achene weight showed a highly significant and positive correlation between biological yield and achene yield $(r=0.884$, and 0.863$)$. Harvest index exhibited a highly significant and positive correlation with achene yield $(\mathrm{r}=0.799)$. The biological yield recorded a highly significant and positive correlation with achene yield $(r=0.927)$. 
Table 7. Simple correlation among all pairs of characters at first location

\begin{tabular}{|c|c|c|c|c|c|c|c|c|}
\hline Characters & $\begin{array}{c}\text { Head } \\
\text { diameter } \\
(\mathrm{cm})\end{array}$ & $\begin{array}{c}\text { Head } \\
\text { weight } \\
\text { (g) }\end{array}$ & $\begin{array}{c}\text { Achene } \\
\text { Weight } \\
\text { (g) }\end{array}$ & $\begin{array}{c}\text { No. of } \\
\text { Achenes } \\
\text { plant }^{-1}\end{array}$ & $\begin{array}{c}1000 \\
\text { Achene } \\
\text { weight (g) }\end{array}$ & $\begin{array}{c}\text { Harvest } \\
\text { index }\end{array}$ & $\begin{array}{c}\text { Biological } \\
\text { yield } \\
\left(\mathbf{k g ~ h a}^{-1}\right)\end{array}$ & $\begin{array}{c}\text { Achene } \\
\text { yield } \\
\left(\mathrm{kg} \mathrm{ha}^{-1}\right)\end{array}$ \\
\hline $\begin{array}{l}\text { Head diameter } \\
(\mathrm{cm})\end{array}$ & 1 & & & & & & & \\
\hline $\begin{array}{l}\text { Head weight } \\
\text { (g) }\end{array}$ & $0.812 * *$ & 1 & & & & & & \\
\hline Achene weight & $0.855 * *$ & $0.968^{* * *}$ & 1 & & & & & \\
\hline No. of Achenes plant ${ }^{-1}$ & $0.947 * *$ & $0.826 * *$ & $0.916 * *$ & 1 & & & & \\
\hline $\begin{array}{l}1000 \text { Achene weight } \\
\text { (g) }\end{array}$ & 0.569 & $0.933 * *$ & $0.863 * *$ & 0.600 & 1 & & & \\
\hline Harvest index & $0.915 * *$ & $0.759 *$ & $0.799 * *$ & $\mathbf{0 . 8 5 2} * *$ & 0.539 & 1 & & \\
\hline $\begin{array}{l}\text { Biological yield } \\
\quad\left(\mathrm{kg} \mathrm{ha}^{-1}\right)\end{array}$ & $0.668 *$ & $0.907 * *$ & $0.927 * *$ & $0.792 *$ & $0.884 * *$ & 0.521 & 1 & \\
\hline $\begin{array}{c}\text { Achene yield } \\
\left(\mathrm{kg} \mathrm{ha}^{-1}\right)\end{array}$ & $0.855^{* *}$ & $0.968 * *$ & $0.999 * *$ & $0.916 * *$ & $0.863 * *$ & $0.799 * *$ & $0.927 * *$ & 1 \\
\hline
\end{tabular}

The correlation coefficient between all pairs of study characters for achene yield and its components obtained at the second location present in Table 8. The head diameter showed a highly significant and positive correlation with head weight, achene weight, number of achenes plant ${ }^{-1}$, harvest index, and achene yield $(\mathrm{r}=0.864,0.845,0.927,0.821$, and 0.845$)$ respectively. However, this character produced a significant and positive correlation with biological yield $(\mathrm{r}=0.756)$. A high correlation was recorded between head weight with achene weight, a number of achenes plant ${ }^{-1}$, harvest index, biological yield, and achene yield $(r=0.991,0.882,0.873,0.959$, and 0.991) respectively. The character achene weight exhibited a highly significant and positive correlation with the number of achenes plant ${ }^{-1}$, harvest index, biological yield, and achene yield $(r=0.885$, 0.897, 0.959, and 0.999), respectively. A highly significant and positive correlation was associated with the number of achenes plant ${ }^{-1}$ with harvest index and achene yield $(\mathrm{r}=$ 0.931 , and 0.885), respectively.

Table 8. Simple Correlation among all pairs of characters at the second location

\begin{tabular}{|c|c|c|c|c|c|c|c|c|}
\hline Characters & $\begin{array}{c}\text { Head } \\
\text { diameter } \\
(\mathrm{cm})\end{array}$ & $\begin{array}{c}\text { Head } \\
\text { weight } \\
(\mathrm{g}) \\
\end{array}$ & $\begin{array}{c}\text { Achene } \\
\text { Weight } \\
\text { (g) }\end{array}$ & $\begin{array}{c}\text { No. of } \\
\text { Achenes } \\
\text { plant }^{-1}\end{array}$ & $\begin{array}{c}1000 \\
\text { Achene } \\
\text { weight (g) }\end{array}$ & $\begin{array}{c}\text { Harvest } \\
\text { index }\end{array}$ & $\begin{array}{c}\text { Biological } \\
\text { yield } \\
\left(\mathrm{kg} \mathrm{ha}^{-1}\right)\end{array}$ & $\begin{array}{c}\text { Achene } \\
\text { yield } \\
\left(\mathrm{kg} \mathrm{ha}^{-1}\right)\end{array}$ \\
\hline $\begin{array}{l}\text { Head diameter } \\
(\mathrm{cm})\end{array}$ & 1 & & & & & & & \\
\hline $\begin{array}{c}\text { Head weight } \\
\text { (g) }\end{array}$ & $0.864 * *$ & 1 & & & & & & \\
\hline $\begin{array}{l}\text { Achene weight } \\
\text { (g) }\end{array}$ & $0.845^{* *}$ & $0.991 * *$ & 1 & & & & & \\
\hline No. of Achenes plant ${ }^{-1}$ & $0.927 * *$ & $0.882 * *$ & $0.885 * *$ & 1 & & & & \\
\hline $\begin{array}{l}1000 \text { Achene weight } \\
\text { (g) }\end{array}$ & 0.149 & 0.396 & 0.335 & 0.065 & 1 & & & \\
\hline Harvest index & $0.821 * *$ & $0.873 * *$ & $0.897 * *$ & $0.931 * *$ & -0.019 & 1 & & \\
\hline $\begin{array}{l}\text { Biological yield } \\
\quad\left(\mathrm{kg} \mathrm{ha}^{-1}\right)\end{array}$ & $0.756 *$ & $0.959 * *$ & $0.959 * *$ & $0.763 *$ & 0.535 & $0.750 *$ & 1 & \\
\hline $\begin{array}{l}\text { Achene yield } \\
\left(\mathrm{kg} \mathrm{ha}^{-1}\right)\end{array}$ & $0.845^{* *}$ & $0.991 * *$ & $0.999 * *$ & $\mathbf{0 . 8 8 5}^{* *}$ & 0.335 & $0.897 * *$ & $0.959 * *$ & 1 \\
\hline
\end{tabular}

** Correlation is significant at 0.01 probability level, $*$ Correlation is significant at 0.05 probability level 
Moreover, the same trait produced a significant and positive correlation with biological yield $(\mathrm{r}=0.763)$. Harvest index showed a highly significant and Correlation values with achene yield $(\mathrm{r}=0.897)$, while the Correlation was significant and positive with biological yield $(r=0.750)$. The biological yield showed a highly significant and positive correlation with the achene yield $(r=0.959)$.

The data were subjected to path analysis to determine the relative importance of the characters. Figures 1 and 2, explain the path coefficient analysis direct (Diagonal) and indirect (Sub diagonal) effect of various characters on sunflower achene yield at both locations. The path coefficient analysis at both locations revealed that achene weight had a higher positive direct effect on achene yield reached (1.00). In contrast, all other characters showed a low positive and negative direct effect on the achene yield. Thus, the maximum positive indirect effect was $(0.968$, and 0.991$)$ recorded by achene weight via head weight, and followed by $(0.927$, and 0.959$)$ for achene weight via biological yield at both locations respectively.

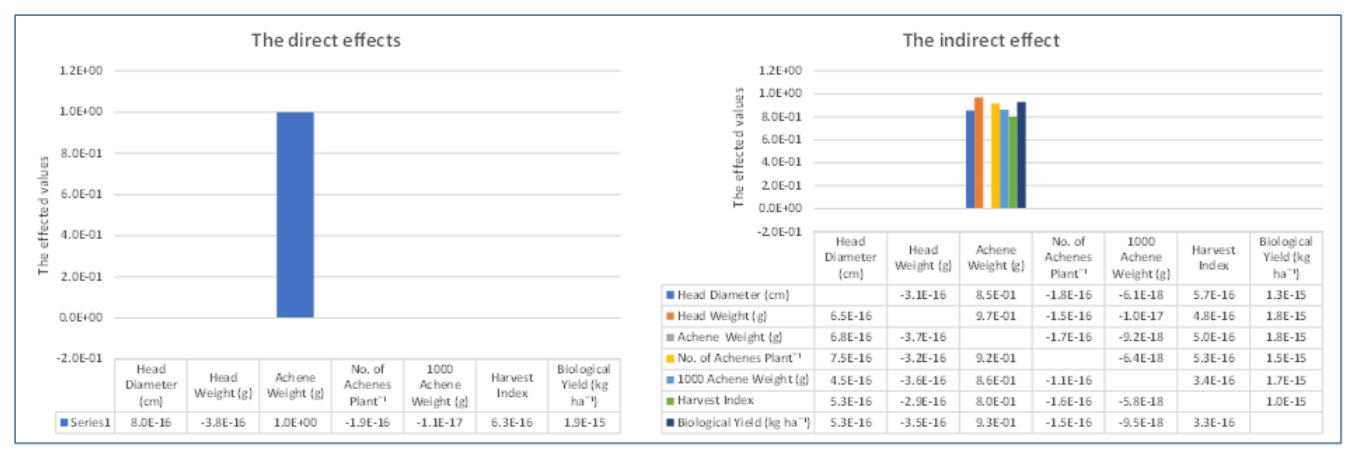

Figure 1. Direct and indirect effects on achene yield and it is components at the first location

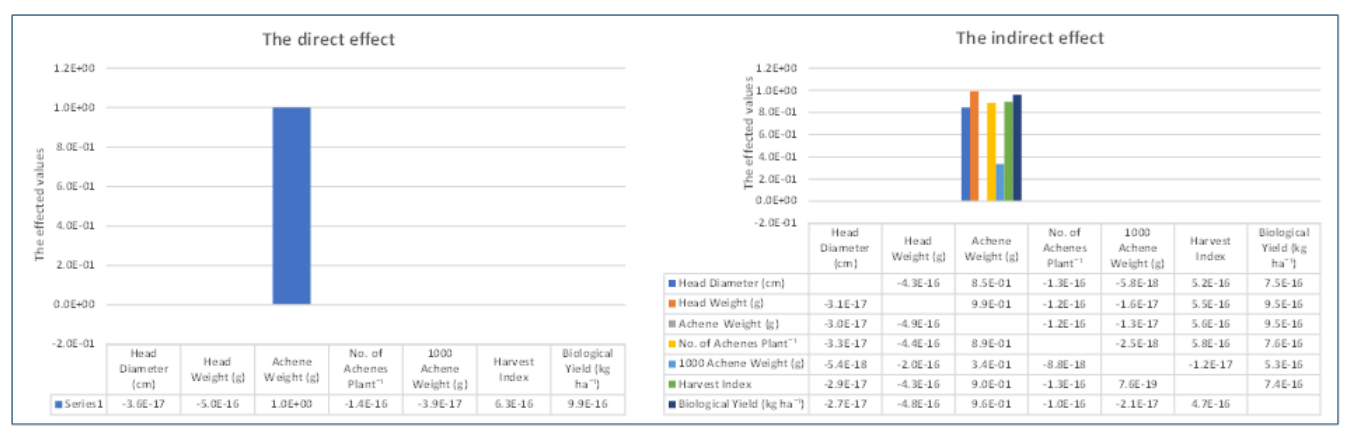

Figure 2. Direct and indirect effects on achene yield and it is components at the second location

\section{Discussion}

The NPK application under field conditions was examined on three sunflower genotypes for some agronomic parameters as well as for achene yield. The treatments were comprised of fertigation and foliar NPK $(20,20,20)$ application, with control NPK $(0,0,0)$, combined with three sunflowers (Sevar, Dea, and Local) genotypes.

The study results indicated that sunflower yield and its components were significantly different due to the NPK application, the treated plot (fertigation and foliar application) and control plot showed different values for achene yield and its components. Fertigation 
application produced a plant with a higher head diameter, leading to an increase in the achene weight and finally leading to maximum achene yield compared to control application. These results collaborate with Malik et al. (2004) that increasing levels of N, $\mathrm{P}$, and $\mathrm{K}$ increased yield, and it is components of sunflower (head diameter, number of achenes head ${ }^{-1}$, 1000-achene weight). However, the statistical variation showed no significant differences between fertigation and foliar application at both locations and their average for all studied characters. These results collaborated with the work of Kaka (2008), who examined the effect of foliar application on sunflower yield and concluded that Urea $(\mathrm{N})$ as foliar spray significantly increase sunflower yield and yield components. It is a well-established fact that foliar application of $\mathrm{N}$ in the form of Urea enhances vegetable growth and yield components compare to control treatment. This enhancement may be due to cell division and expansion, which increase the rate of photosynthesis, which ultimately, increase the chlorophyll content by increasing the rubisco activity (Brady and Weil, 2005; Kaka, 2008; Hassanlouee and Baghbani, 2013). Also, Iqbal et al. (2008) reported a progressive increase in achene yield, and it is components with increasing levels of $\mathrm{N}, \mathrm{P}$, and $\mathrm{K}$.

The study witnessed a significant effect of sunflower genotypes; therefore, the increase of achene yield depends on genotypes and NPK application. Notably, the Dea genotype exceeded Sevar and Local genotype in achene yield, and most of it is components. Our results collaborate Ozer et al. (2004) and Zheljazkov et al. (2008), who reported significant differences in yield potential among various sunflower hybrids.

The effect of interaction between foliar NPK application on achene yield of Dea sunflower genotype at both locations and their average was significantly notable, as assessed from the higher head weight and achene weight over the other combinations between fertilizer application and genotypes. The same results were reported by Abbasi et al. (2005). Foliar feeding of nutrients may promote the root absorption of the same nutrient or other nutrients through improving root growth and increasing nutrients uptake (Saqib et al., 2006).

The exceeding of achene yield and its components in the first location may be due to the favorable environmental conditions prevailing in this location to grow this crop. Higher seed yields may be due to different environmental conditions at each location.

Head weight was affected by environmental factors, and also final seed yield was significantly affected by environmental factors. Also, Sidlauskas and Bernotas (2003) and Denčić et al. (2012) concluded that productivity and quality are highly influenced by genotype, environment, and interaction.

The correlation coefficient between achene yield and most of the studied characters were positively and highly significant at both locations. Selection of head diameter, head weight, achene weight, number of achenes plant ${ }^{-1}$, harvest index, and biological yield recorded a highly significant and positive correlation with achene yield. The results align with the earlier findings of Hladni et al. (2006), Khokhar et al. (2006), Srimuenwai (2006), Kaya et al. (2007), Machikowa and Saetang (2008), Sowmya et al. (2010), Patil (2011), Pivetta et al. (2012), and Singh et al. (2018).

Path coefficient analysis showed that achene weight has the highest direct and indirect positive effect on achene yield. Thus, the achene weight had a more substantial influence on the achene yield of sunflower. Shankar et al. (2006); Arshad et al. (2007); and Hidyatullah et al. (2008) applied the path coefficient by partitioning the genotypic correlations into direct and indirect effects of the traits. However, Habib et al. (2006) reported positive direct effects of the number of seed per head on seed yield. However, 
Ashoke et al. (2000); and Tahir et al. (2002) also studied the positive direct effect of head diameter and 100-achene weight on achene weight per head. Therefore, it can be concluded that direct and indirect selection of achene weight can improve sunflower achene yield.

\section{Conclusion and Recommendation}

The results obtained from this study concluded that fertigation and foliar application of NPK increase the diameter of the sunflower head. Therefore, a larger head size produced a higher number of achenes. This increase in the number of achenes per head ultimately increases seed yield. Thus, it is recommended to conduct further study to investigate the effect of fertigation and foliar applications of NPK on sunflower seed oil content. More studies are also needed to determine the influence of this type of NPK application on the number of achenes per head at different growing seasons.

\section{REFERENCES}

[1] Abassi, M. K., Kazmi, M., Hussan, F. U. (2005): Nitrogen use efficiency and herbage production of an established grass sward in relation to moisture and nitrogen fertilization. - Journal of plant nutrition 28(10): 1693-1708.

[2] Adediran, J. A., Taiwo, L. B., Akande, M. O., Sobulo, R. A., Idowu, O. J. (2005): Application of organic and inorganic fertilizer for sustainable maize and cowpea yields in Nigeria. - Journal of plant nutrition 27(7): 1163-1181.

[3] Ahmed, A. G., Orabi, S. A., Gaballah, M. S. (2010): Effect of bio-NP fertilizer on the growth, yield and some biochemical components of two sunflower cultivars. - International Journal of Academic Research 2(4).

[4] Akbari, P., Ghalavand, A., Sanavy, A. M., Alikhani, M. A. (2011): The effect of biofertilizers, nitrogen fertilizer and farmyard manure on grain yield and seed quality of sunflower (Helianthus annuus L.). - Journal of Agricultural Technology 7(1): 173-184.

[5] Alberio, C., Izquierdo, N. G., Aguirrezábal, L. A. N. (2015): Sunflower crop physiology and agronomy. - AOCS, Elsevier, pp. 53-91.

[6] Aquino, L. A. D., da Silva, F. D., Berger, P. G. (2013): Agronomic characteristics and nutritional status of irrigated sunflower cultivars. - Revista Brasileira De Engenharia Agrícola E Ambiental 17(5): 551-557.

[7] Arshad, M., Ilyas, M. K., Khan, M. A. (2007): Genetic divergence and path coefficient analysis for seed yield traits in sunflower (Helianthus annuus L.) hybrids. - Pak. J. Bot 39(6): 2009-2015.

[8] Ashoke, S., Mohamed Sheriff, N., Narayanan, S. L. (2000): Character association and path coefficient analysis in sunflower. - Crop Res 20(3): 453-456.

[9] Brady, C. N., Weil, R. R. (2005): The nature and properties of soils. - Pearson Education, Inc.

[10] Chen, J. H. (2006): The combined use of chemical and organic fertilizers and/or biofertilizer for crop growth and soil fertility. - International workshop on sustained management of the soil-rhizosphere system for efficient crop production and fertilizer use 16(20): 1-11.

[11] Darby, H., Harwood, H., Cummings, E., Madden, R., Monahan, S. (2013): 2012 Sunflower population and nitrogen rate trial. - Northwest Crops \& Soils program 253.

[12] Demir, A. O., Göksoy, A. T., Büyükcangaz, H., Turan, Z. M., Köksal, E. S. (2006): Deficit irrigation of sunflower (Helianthus annuus L.) in a sub-humid climate. - Irrigation Science 24(4): 279-289. 
[13] Denčić, S., Mladenov, N., Kobiljski, B. (2012): Effects of genotype and environment on breadmaking quality in wheat. - International Journal of plant production 5(1): 71-82.

[14] Habib, H., Mehdi, S. S., Rashid, A., Anjum, M. A. (2006): Genetic association and path analysis for seed yield in sunflower (Helianthus annuus L.). - Pak. j. Agri. Sci 43(3-4): 136-139.

[15] Hakim, K., Hidayat, R., Bakht, J., Sher, A. K., Ayub, K. K. (2013): Genotype X Environment interactions and heritability estimates for home agronomic characters in sunflower. - The J. Anim. and Plant Sci. 23: 1177-1184.

[16] Haseeb, M., Maqbool, N. (2015): Influence of foliar applied nitrogen on reproductive growth of sunflower (Helianthus annuus L.) under water stress. - Agricultural Sciences 6(12): 1413

[17] Hassan, S. W. U. L., Oad, F. C., Shamasuddin, T., Gandahi, A. W., Siddiqui, M. H., Oad, S. M., Jagirani, A. W. (2010): Effect of N application and N splitting strategy on maize N uptake, biomass production and physio-agronomic characteristics. - Sarhad Journal of Agriculture 26(4): 551-558.

[18] Hassanlouee, M., Baghbani, F. (2013): Effects of stages and amount of nitrogen foliar application on yield and yield components in hybrid Alestar sunflower. - ARPN Journal of Agricultural and Biological Science 8(3): 224-226.

[19] Hebbar, S. S., Ramachandrappa, B. K., Nanjappa, H. V., Prabhakar, M. (2004): Studies on NPK drip fertigation in field grown tomato (Lycopersicon esculentum Mill.). - European Journal of Agronomy 21(1): 117-127.

[20] Hidyatullah, M., Jatoi, S. A., Ghafoor, A., Mahmood, T. (2008): Path coefficient analysis of yield component in tomato (Lycopersicon esculentum). - Pak. J. Bot. 40(2): 627-635.

[21] Hladni, N., Škorić, D., Kraljević-Balalić, M., Sakač, Z., Jovanović, D. (2006): Combining ability for oil content and its correlations with other yield components in sunflower (Helianthus annuus L.). - Helia 29(44): 101-110.

[22] Hussain, T. I., Ahmed, M. A., Haq, M. A., Jamil, M., Zia, M. H. (2000): EM TechnologyA new look for IPNM. - Proc. Symp., Integrated Plant Nutrient Management, NFDC, Islamabad, Pakistan.

[23] Iqbal, J., Hussain, B., Saleem, M. F., Munir, M. A., Aslam, M. (2008): Bioeconomics of autumn planted sunflower (Helianthus annuus L.) hybrids under different NPK application. - Pak. J. Agri. Sci. 45(3): 19-24.

[24] Janamma, P., Jabeen, F., Ranganatha, A. (2008): Association analysis in sunflower (Helianthus annuus L.). - J. Res. ANGRAU 36(2-3): 55-59.

[25] Kaka, A. H. (2008): To study the effect of integrated nutrient management on quantitative and qualitative characters of sunflower. - agris.fao.org. 1-76.

[26] Kaya, Y., Evci, G., Durak, S., Pekcan, V., Gücer, T. (2007): Determining the relationships between yield and yield attributes in sunflower. - Turkish Journal of Agriculture and Forestry 31(4): 237-244.

[27] Khokhar, M. I., Sadaqat, H. A., Tahir, M. N. (2006): Association and effect of yield related traits on achene yield in sunflower. - Int. J. Agric. Biol. 8(4): 450-451.

[28] Kumar, S., Asrey, R., Singh, R. (2000): Fertigation: need of modern agriculture. - YojanaDelhi 44(7): 31-33.

[29] Kurdistan Regional Government. (2018): Kurdistan's geography and climate. - Available at: http://cabinet.gov.krd/a/d.aspx?s=010000\&l=12\&a=18656.

[30] Machikowa, T., Saetang, C. (2008): Correlation and path coefficient analysis on seed yield in sunflower. - Suranaree J. Sci. Technol 15(3): 243-248.

[31] Malik, M. A., Saleem, M. F., Sana, M., Rehman, A. (2004): Suitable level of N, P and K for harvesting the maximum economic returns of sunflower (Helianthus annuus L.). International Journal of Agriculture and Biology (Pakistan) 6(2): 240-242.

[32] Murphy, D. J. (2010): Improvement of industrial oil crops. - In: Singh, B. P. (ed.) Industrial crops and uses. CABI International, Cambridge, pp. 183-206. 
[33] Nasreen, S., Khan, M. A., Zia, M., Ishaque, M., Uddin, S., Arshad, M., Zarrin, F. (2015): Response of sunflower to various pre-germination techniques for breaking seed dormancy. - Pakistan Journal of Botany 47(2): 413-416.

[34] Onemli, F., Gucer, T. (2010): Response to drought of some wild species of Helianthus at seedling growth stage. - Helia 33(53): 45-54.

[35] Ozer, H., Polat, T., Ozturk, E. (2004): Response of irrigated sunflower (Helianthus annuus L.) hybrids to nitrogen fertilization: growth, yield and yield components. - Plant Soil and Environment 50(5): 205-211.

[36] Patil, L. C. (2011): Research note correlation and path analysis in sunflower populations. - Electronic Journal of Plant Breeding 2(3): 442-447.

[37] Pivetta, L. G., Guimarães, V. F., Fioreze, S. L., Pivetta, L. A., Castoldi, G. (2012): Evaluation of sunflower hybrids and the relationship between productive and qualitative parameters. - Revista Ciência Agronômica 43(3): 561-568.

[38] Popoola, O., Adesanya, K., Olawale, O., Ayanrinde, A. (2016): Factorial analysis on the effect of NPK fertilizer, micronutrients and N-placement on the growth and yield of sunflower. - IJESR 4(1): 22-37.

[39] Rauf, S., Jamil, N., Tariq, S. A., Khan, M., Kausar, M., Kaya, Y. (2017): Progress in modification of sunflower oil to expand its industrial value. - Journal of the Science of Food and Agriculture 97(7): 1997-2006.

[40] Saqib, M., Zörb, C., Schubert, S. (2006): Salt-resistant and salt-sensitive wheat genotypes show similar biochemical reaction at protein level in the first phase of salt stress. - Journal of Plant Nutrition and Soil Science 169(4): 542-548.

[41] Scheiner, J. D., Gutiérrez-Boem, F. H., Lavado, R. S. (2002): Sunflower nitrogen requirement and $15 \mathrm{~N}$ fertilizer recovery in Western Pampas, Argentina. - European Journal of Agronomy 17(1): 73-79.

[42] Shafi, M., Bakht, J., Yousaf, M., Khan, M. A. (2013): Effects of irrigation regime on growth and seed yield of sunflower (Helianthus annuus L.). - Pak. J. Bot 45(6): 1995-2000.

[43] Shankar, V. G., Ganesh, M., Ranganatha, A. R. G., Bhave, M. H. V. (2006): A study on correlation and path analysis of seed yield and yield components in sunflower (Helianthus annuus L.). - Agricultural Science Digest 26(2): 87-90.

[44] Siddiqi, M. H., Ali, S., Bakht, J., Khan, P., Aslam, S., Khan, N. (2012): Evaluation of sunflower lines and their crossing combinations for morphological characters. yield and oil contents. - Pak. J. Bot. 44(2): 687-690.

[45] Sidlauskas, G., Bernotas, S. (2003): Some factors affecting seed yield of spring oilseed rape (Brassica napus L.). - Agronomy Research 1(2): 229-243.

[46] Singh, I., Stoskopf, N. (1971): Harvest index in cereal 1. - Agronomy Journal 63(2): 224226.

[47] Singh, V. K., Chander, S. (2018): Correlation analysis for seed yield and its component traits in sunflower. - Journal of Pharmacognosy and Phytochemistry 7(3): 2299-2301.

[48] Sowmya, H. C., Shadakshari, Y. G., Pranesh, K. J., Srivastava, A., Nandini, B. (2010): Character association and path analysis in sunflower (Helianthus annuus L.). - Electronic Journal of Plant Breeding 1(4): 828-831.

[49] Srimuenwai, P. (2006): Improvement of agronomic characters, oil content and yield of synthetic varieties of sunflower. - M. Sc. thesis, School of Crop Production Technology, Institute of Agriculture. Suranaree University of Thechnology, Thailand, 80p.

[50] Tahir, M. H. N., Sadaqat, H. A., Bashir, S. (2002): Correlation and path coefficient analysis of morphological traits in sunflower (Helianthus annuus L.) populations. - Int. J. Agri. Biol 4(3): 341-343.

[51] Taran, S. A., Baloch, D. M., Khan, N. U., Bakht, J., Ghaloo, S. H., Shahwani, M. N., Kakar, M. S. (2013): Earliness and yield performance of sunflower hybrids in uplands of Balochistan, Pakistan. - Pak. J. Bot 45(4): 1397-1402. 
[52] Tuo, D., An, H., Zhang, J., Li, Z. H. (2010): The current situation of sunflower fertilizer technology at home and aboard and its development tread. - Inner Mongolia Agricultural Science and Technology 6: 1-2.

[53] Varga, B., Svečnjak, Z. (2006): The effect of late-season urea spraying on grain yield and quality of winter wheat cultivars under low and high basal nitrogen fertilization. - Field Crops Research 96(1): 125-132.

[54] XLSTAT version (2016): XLSTAT 2016. - Data analysis and statistics with Microsoft Excel, Paris, France, MacOS ed.

[55] Zheljazkov, V. D., Vick, B. A., Ebelhar, M. W., Buehring, N., Baldwin, B. S., Astatkie, T., Miller, J. F. (2008): Yield, oil content, and composition of sunflower grown at multiple locations in Mississippi. - Agronomy Journal 100(3): 635-642.

\section{APPENDIX}

Mean squares of variance analysis for achene yield and its components at both locations and their average

\begin{tabular}{|c|c|c|c|c|c|c|c|c|c|}
\hline S.O.V & d.f & $\begin{array}{c}\text { Head } \\
\text { diameter } \\
(\mathrm{cm})\end{array}$ & $\begin{array}{c}\text { Head } \\
\text { Weight } \\
\text { (g) }\end{array}$ & $\begin{array}{c}\text { Achene } \\
\text { weight } \\
\text { (g) }\end{array}$ & $\begin{array}{c}\text { No. of } \\
\text { achenes }^{-1} \\
\text { plant }^{-1}\end{array}$ & $\begin{array}{c}1000 \\
\text { Achene } \\
\text { weight } \\
\text { (g) } \\
\end{array}$ & $\begin{array}{c}\text { Harvest } \\
\text { index }\end{array}$ & $\begin{array}{c}\text { Biological } \\
\text { yield } \\
\left(\mathrm{kg} \mathrm{ha}^{-1}\right)\end{array}$ & $\begin{array}{c}\text { Achene } \\
\text { yield } \\
\left(\mathrm{kg} \mathrm{ha}^{-1}\right)\end{array}$ \\
\hline \multicolumn{10}{|c|}{ First location } \\
\hline Block & 2 & 41 & 545.9 & 7.424 & 98144.94 & 10.573 & .0006 & 7 & 8 \\
\hline $\begin{array}{c}\text { NPK } \\
\text { application }\end{array}$ & 2 & $93.804 * *$ & $24911.43 * *$ & 9725 & $902047.4 * *$ & $808.189 * *$ & $0.0216^{*}$ & $1.19 \mathrm{E}+08 * *$ & $43226305^{* *}$ \\
\hline $\mathrm{E}(\mathrm{a})$ & 4 & 0.456 & 37 & 15 & & 14.568 & 0.0 & & \\
\hline Geno & 2 & 50. & 758 & 6240 & 955 & $444.477 *$ & 0.0 & 1.8 & 277 \\
\hline $\begin{array}{c}\text { NPK * } \\
\text { Genotype }\end{array}$ & 4 & 2 & 5 & 5 & 970 & $44.524 *$ & ) & v. $s$ & $2273242 *$ \\
\hline & 12 & 0.576 & 167.796 & 117.483 & 24201.02 & 11.349 & 0.0012 & 148 & 522152.3 \\
\hline \multicolumn{10}{|c|}{ Second location } \\
\hline $\mathrm{Bl}$ & 2 & 24 & 7 & 349.104 & & 17.14 & 0.0004 & & 155 \\
\hline $\begin{array}{c}\text { NPK } \\
\text { application }\end{array}$ & 2 & $31.667 * *$ & $9233.879 *$ & $3800.107 *$ & $349273.7 * *$ & $227.631 * *$ & $0.0067^{\text {N.S }}$ & $1.05 \mathrm{E}+08^{* *}$ & $16889532 *$ \\
\hline & 4 & 0.264 & 444.530 & 4 & & 8.913 & 0.0 & 3811504 & \\
\hline Genotype & 2 & 53.2 & 4844 & 3065 & 669 & $70.682 *$ & $0.0146^{*}$ & 4828 & 136 \\
\hline $\begin{array}{c}\text { NPK * } \\
\text { Genotype }\end{array}$ & 4 & 1. & $32 \varepsilon$ & 12 & 5 & $22.589^{\mathrm{N} . S}$ & $0.0029 *$ & $15^{\mathrm{N} . \mathrm{S}}$ & 663 \\
\hline & 12 & 446 & 0851 & 31.009 & 10844.51 & 12.100 & 0.0007 & 92 & 13 \\
\hline \multicolumn{10}{|c|}{ Average of both locations } \\
\hline Loc & 1 & $* *$ & 9939 & $406524.3^{* *}$ & & $153626.8^{* *}$ & & & 1.8 \\
\hline $\begin{array}{c}\text { Block/L } \\
\text { E(a) }\end{array}$ & 4 & 1.832 & 120 & 17 & 104 & 13.856 & 0.0005 & 6425277 & 792292.4 \\
\hline $\begin{array}{c}\text { NPK } \\
\text { application }\end{array}$ & 2 & $117.202 * *$ & $32160.79 * *$ & $12805.55 * *$ & $1171728 * *$ & $916.119 * *$ & $0.0263 * *$ & $2.23 \mathrm{E}+08 * *$ & $56914111 * *$ \\
\hline Lo & 2 & 8.26 & 198 & 720 & 795 & 119.701 & 0.0021 & 85 & 32 \\
\hline & 0 & & & & & & & & \\
\hline & 2 & $103.945^{* *}$ & 11229 & 8920 & 159 & $278.361 * *$ & $0.0189 * *$ & 2.07 & 396 \\
\hline $\begin{array}{c}\text { Genotype * } \\
\text { Location }\end{array}$ & 2 & 0.099 & 1198.131 & 385.513 & 29247.4 & 236.798 & 0.0033 & 27332793 & 1713410 \\
\hline $\begin{array}{c}\text { NPK * } \\
\text { Genotype } \\
\text { NPK * }\end{array}$ & 4 & $3.375 * *$ & $696.316^{* *}$ & $494.126^{* *}$ & $119764 * *$ & $37.82 *$ & $0.0027 *$ & $1211356^{\mathrm{N} . \mathrm{S}}$ & $2196136 * *$ \\
\hline $\begin{array}{c}\text { Genotype * } \\
\text { L }\end{array}$ & 4 & 0.482 & 230.921 & 166.524 & 30070.77 & 29.293 & 0.0042 & 946842.4 & 740112.5 \\
\hline $\mathrm{E}(\mathrm{c}) / \mathrm{L}$ & 24 & .511 & 124.324 & 74.246 & 17522.77 & 11.725 & 0.0009 & 1202898 & 329985.9 \\
\hline
\end{tabular}

LSD value at $\mathrm{P} \leq 0.01=$ Highly significant $* *$, LSD value at $\mathrm{P} \leq 0.05=$ Significant *, N. S. = Statistically non-significant 